\title{
Correction to: Amikacin Liposome Inhalation Suspension: A Review in Mycobacterium avium Complex Lung Disease
}

\section{Matt Shirley ${ }^{1}$}

Published online: 3 April 2019

(c) Springer Nature 2019

\section{Correction to: Drugs (2019) 79:555-562 https://doi.org/10.1007/s40265-019-01095-z}

The article Amikacin Liposome Inhalation Suspension: A Review in Mycobacterium avium Complex Lung Disease, written by Matt Shirley, was originally published Online First without open access. After publication in volume 79, issue 5, pages 555-562 Insmed Incorporated requested that the article be Open Choice to make the article an open access publication. Post-publication open access was funded by Insmed Incorporated. The article is forthwith distributed under the terms of the Creative Commons Attribution-NonCommercial 4.0 International License (http://creativecommons .org/licenses/by-nc/4.0/), which permits any noncommercial use, duplication, adaptation, distribution and reproduction in any medium or format, as long as you give appropriate credit to the original author(s) and the source, provide a link to the Creative Commons license and indicate if changes were made.

The original article has been corrected.

Open Access This article is distributed under the terms of the Creative Commons Attribution-NonCommercial 4.0 International License (http://creativecommons.org/licenses/by-nc/4.0/), which permits any noncommercial use, distribution, and reproduction in any medium, provided you give appropriate credit to the original author(s) and the source, provide a link to the Creative Commons license, and indicate if changes were made.
The original article can be found online at https://doi.org/10.1007/ s40265-019-01095-z.

Matt Shirley

demail@springer.com

1 Springer, Private Bag 65901, Mairangi Bay, Auckland 0754, New Zealand 